\title{
ANALYSIS OF CHARACTERIZATION OF THE MAIN CHARACTERS OF "FIRST THEY KILLED MY FATHER" MOVIE BY ANGELINA JOLIE
}

\author{
Trisnian Ifianti ${ }^{1)}$, Anita Kurnia Rahman ${ }^{2)}$ \\ ${ }^{1) 2}$ IKIP Budi Utomo Malang \\ nianitubungas15@gmail.com
}

\begin{abstract}
Literary work, especially film, gives life a lot of inspiration. Movie makes the reader aware that the story that happens in a movie is a reflection of a real life. Characters are characters in stories, and traits are the reasons why a character does things. In fact, there are several explanations why in the Movie Script "First They Killed My Father," the researcher was interested in studying literature on cinema, first this film had some amazing characters. Secondly, this film will encourage everybody to fight arbitrariness and anti violent campaigns.. Statements of the problem of research are: What is the physical appearance of the main characters, how is the main character's personality, how are the main characters ' social status, how are the main characters' social relations. This study is intended to clarify the presence of the main characters, their personality, the social position of the main characters, their social relationship with the main characters. The method used in this study is qualitative research, and the findings of the investigations are all phrases and dialogs between characteristics related to the characterization of the film. The results of this research show that the main characters Loung Ung and Pa, Loung Ung's Father, named Mr. Ung have made a great contribution to the plot. Characterization concerns the main characters ' physical appearance, personality and social status. Loung Ung's physical appearance are little girl, slender build, average hair, caramel skin. Pa or Mr. Ung physical appearances are average build, male, moon shape eyes, and caramel skin. Both of the main character have brave personalities, love and care, and love the whole family. For the social status they are moderate family and live in apartment in the city . Pa or Mr.Ung is well educated person because he is an officer. Pa or Mr.Ung has a good social relationship with the people surrounding, but Loung Ung doesn't have a good social relationship with the people surrounding her because she is passive.
\end{abstract}

Keywords: Analysis, Character and characterization

CPendidikan Bahasa Inggris FPISH IKIP BU Malang

\section{Introduction}

Literature has now been used as an instrument to express what one feels to be a beautiful play of words, such as figurative language, or connotative meanings expressed in literary works. Djoko (2003: 36) argued that literary work is imaginative, connotative in language and has an esthetic element. Literature is the embodiment of knowledge of the art of language, capable of vibrating the soul in the form of writing. As a source of knowledge, literature automatically acts as' life teachers' as a source of knowledge. Literature does not overflow, because the other side of the literature also acts as force. The power of this case can be interpreted as a driver or an extrinsic motivator. This power can have a significant impact on our next life journey. Because of this process, we will also find knowledge and experience, without having to go on a real day of life. Literature seeks to explain, understand and open up new insights and to give meaning to life's reality, in order to better understand human beings and adapt them to the reality of life (imagination). Literature can influence a person's way of life thinking and living and living in every color of life. Literary activity is mainly aimed at improving the mind, the imagination and the expression. As a product of human culture, literature includes values which live and apply in society. The literature arising from a long process of contemplation on the nature of life and existence is the processing of the soul of its creator. So it actually listens to the writer when break an article in our 
imagination. Sometimes, thoughts of a person can only be spread directly or in writing through the spoken language. With today's technology creation, feelings, ideas, and research can be conveyed with visual media. A literary work is more alive with the film industry. Movie provides an art form that is innovative and exceptional in its capacity to convey information and messages. Films are used to satisfy a shared need to convey an idea, message or reality. There are actually several ways of expressing ideas, especially in films. Therefore, the use of language in film can make the film categorized as a literary work. The authors have characters in relation to literature in some films and literary works. One of the elements of literature is characterization. The character is a value embodied in behaviors according to Vidya (2015:76-78,

Analyzing films by characters can make society more precise, because humanity itself can affect characteristics in the psychological aspects. An interesting story can be told when it depends on the characters ' play, because the characters are the key to the way in which the story is lived. In this case, someone, things, although the author may be the character, but they have to play in the story of the film. Humanity factors may affect their social lives, their everyday behaviors, their interactions or perhaps when they adjust to a situation they've never experienced before. When we watch films, we can develop our knowledge automatically, especially characterization and characterization of the plot. Character is widely regarded as an essential element in fiction, in particular in novel and play. Characterization is called the process of creating and developing character in a work fiction. Characterization, by this definition, means a true description of the characters who take part in the story through their actions. Characterizations or disposition is a technique or a means of showing figures. According to Jones (1968:84) there are a number of ways to show the character. Analytical way, is how the characters appear directly through the author's description. The author only analyzes and studies the characterization of the main characters, and the main characters are based on this aspect:

1. Physical appearance of the main characters.

It contains the physical appearances, related to their age, performance, describing how old they are, how they look, about the sex of both men and women, like pale skin, beautiful, long, black or brown, etc.

2. Social status of the main characters.

This section describes how life's principal character (rich or poor) is, how dignity of education and treasure is. And discusses the background of the main character, such as: their background in education, their middle, high modern class life.

3. Social relationship of the main characters.

In this case, the writer would like to discuss the relationship between the main characters and the other characters around them (minor character or supporting character).

4. Personality of the main characters It describes the personality of the main person such as: how to create a romantic situation, whether or not they are responsible, clean persons or disciplines, can see good condition in their role.

So that's what the researcher took the title "Analysis of characterization of 
the main character of " First They Killed My Father" movie by Angelina Jolie".

First they killed My Father's memory of the Khmer Rouge Killing Fields survivor Loung Ung. As an adult she wrote the story of her childhood between five and 9 years old. It begins with her glamorous life as a young daughter of a middle class family in Phnom Penh, Cambodia's capital. Her dad worked for the Cambodian government, helping the family to lead a good life with a lot of food, clean clothing and quality schools. When the Khmer Rouge took over the country, everything changed. The study elaborates the portrayal of the main characters, their physical appearance, the main characters ' personalities, social status, social relationship, film as a source of data, and the data consists of film script, memoar, and viewing of movies.

\section{Research Method}

This study used qualitative description research since data collection is needed in order to describe the existing condition. It was a research design part of the qualitative method that allowed the researcher to describe the phenomenon by presenting the facts in rich detail without trying to interpret them. It is said to be qualitative because it explains concepts related to each other by using words or sentences instead of using statistical numbers.

Data were generally described and analyzed according to specific parts of information and data that were used as the basis for the solution of the problem from certain theories. The researcher as the main instruments of the research used the movie as the main data and the data collection technique used is as follows:

1. Watching the movie repeatedly and carefully.
2. Reading and learning all the phrases in the script text and the memoir.

3. Identifying for the purpose of finding data related to the research.

4. Classifying the data.

5. Selecting the data which relevant to the problem.

6. Reporting the selected data

The analysis of the data was a technique in which data were systematically formed and arranged, grouped into categories, defined data in units, arranged and made a conclusion. Steps of analysis of the data:

a. Collect relevant referrals to the data analysis.

b. Description of the data

c. Extract the characterization that the movie implied by the main characters.

d. Make the data analysis and conclusion to address the question in the statement of the problem.

\section{Result and Discussion}

This segment describes the findings in depth and examines the features and quality of the film itself. The researcher considered two main characters in the film. They are Loung Ung her father Pa. Each is elaborated below.

\section{A. Findings and Analyzing of Main Character Physical characteristicss}

As described, the physical appearance explains how old they are, who they look like, their sex (the main characters are man or woman, the main characters have pale skin, pretty, beautiful, thin, black, brown or white hair, etc.). There are two main characters in the movie. They are:
A.1 Loung Ung 
Loung Ung is a little girl, sweet looking, Asian's skin, slender build, and short hair. Loung's physical appearance can be seen in the narration of the movie below:

Data 1:

"The little girl turns and walks toward a view not dissimilar to the one near the American embassy on the news. Little caramel colored legs and feet on a balcony. The edge of a skirt in the wind identifies the child as a little girl"

Data analysis:

The little girls is Loung, who seen the dissimilar view near the American embassy. Little girl with caramel skin, dan little feet.

\section{Data 2:}

"Pa and a colleague of his enter the room. Loung jumps into his arms. $\mathrm{Pa}$ is loved for his generous heart. He reminds Loung of a teddy bear."

Data analysis:

Loung has slender build which her pa can take her into his arm. And also Loung is only a little girl who still play Teddy bear.

\section{A.2. $\mathrm{Pa} / \mathrm{Mr}$. Ung}

$\mathrm{Pa} / \mathrm{Mr}$. Ung is male. $\mathrm{He}$ is an officer of Khmer National Armed Force. Avearge build, and caramel skin, has an Cambodian eyes. It can be seen in the data below:

Data 1 :

"Pa is loved for his generous heart. He reminds Loung of a teddy bear. His eyes are warm and brown and shaped like the moon. Loung plays with the four stripes on his uniform. Pa greets her and asks about her day".

Data analysis:

Mr. Ung has warm and moon shaped eyes.

\section{B. Finding and Analyzing on the the main character's personality}

As stated, it is intended to describe the personality of the main character, such as: how to create a romantic situation, can see a good condition for playing a role, whether or not they are responsible, neat persons or discipline.

\section{B.1. Loung Ung}

Loung Ung is little girl with high curiosity, loves her ma and pa, braves and has a high nationality. It can be seen on the data bellow:

Data 1:

"She begins to climb to the top of the railing. Her little hands and feet. The sound of a helicopter coming towards her. Finally she reaches the top. She watches as a helicopter almost identical to the one on the television flies low over her head. This brave free spirited little girl is Loung."

Data analysis:

The narration show that Loung is brave to climb the railing and watches the situation.

\section{Data 2:}

"Loung watches Chou sleeping. She looks over at the empty place where Meng, Khouy and Keav used to sleep. Tears fall from her big brown eyes."

Data analysis:

Loung loves her family alots. When they live a part Loung feels sad of missing.

\section{B.2. $\mathrm{Pa} / \mathrm{Mr}$.Ung}

$\mathrm{Pa} / \mathrm{Mr}$. Ung is kindhearted, loves and cares the family. He is nationalist who does everything for his country. It can be seen from the data below:

\section{Data 1:}

"Pa is loved for his generous heart. He reminds Loung of a teddy bear. His eyes are warm and brown and shaped like the moon. Loung plays with the four stripes on his uniform. Pa greets her and asks about her day."

Data analysis:

$\mathrm{Pa}$ has been loved by all family because he has generous heart. $\mathrm{He}$ 
always asks Loung's day. and it means a lot for every daughter.

Data 2:

Loung: Do you live here?

Pa: This is where the God live. When you call out, they will answer.

Data analysis:

When Loung asks her Pa, about his country he answer about where the God lives. The country they loved. His nationality shown that whatever the condition the country is the place to live.

Data 3:

Meng: You were once a monk

Pa: I was. But I met a beautiful woman in a pretty blue silk shirt, who's smile melted my heart. The same smile her daughters now have.( Loung smiles)

Data analysis:

$\mathrm{Pa}$ is loving and caring person. $\mathrm{H}$ creates romantic moment with the whole family. He always tries to make Loung smiles.

\section{Finding and Analyzing The main character's social status.}

The social status in this situation affects the main characters of the educational background and their lives. Do the main characters have poor, middle or high school education? Are the main characters of the lower, upper or progressive classes?

C. 1. Loung Ung

Loung Ung and her family is a moderate family in theirs area. Loung lives in apartment which has three floors. The data bellows shown that:

Data 1:

"Little caramel colored legs and feet on a balcony. The edge of a skirt in the wind identifies the child as a little girl. She begins to climb to the top of the railing. Her little hands and feet. The sound of a helicopter coming towards her. Finally she reaches the top. She watches as a helicopter almost identical to the one on the television flies low over her head. This brave free spirited little girl is LOUNG. At five she stands looking out over city from the third floor."

Data analysis:

The data show that Loung and her family live in the apartment with three floors and has balcony. Moderate family who live in the apartement with television dan also in the city.

C.2. $\mathrm{Pa} / \mathrm{Mr}$. Ung

$\mathrm{Pa} / \mathrm{Mr}$. Ung is officer of Khmer National Armed Forces. He is smart and professional. He can speak France.

It shown in the data below:

Data 1:

"Loung plays with the four stripes on his uniform. Pa greets her and asks about her day. Pa's Colleague seems concerned but remains professional. They speak in french (no translation as Loung can't understand as he intends)."

Data analysis:

As an officer $\mathrm{Pa} / \mathrm{Mr}$. Ung work professionally although he is at home and his daughter/ Lung wants to play with him. He speaks France and it shows that he is an educated person.

\section{Finding and Analyzing On The main Character's social relationship.}

This provides data about the relationship between the main character and its surrounding characters. Human beings cannot stand alone to solve a problem. Therefore, when an individual is involved, we definitely need to find a new, strange life. Nevertheless, if a person stands up to his idea and is unable to accept a new life in society, we will of course be in conflict with society.

D.1. Loung Ung

Loung Ung is passive girl. She only speaks with the family and person she know, and it only little speech. She only notice what her parents asked. His high curiosity does not mean much to create her good social life. And also, Loung is vengeful. 
Almost all the data shown that Loung Ung is passive girl.

Data 1:

They speak in french (no translation as Loung can't understand as he intends). Because she can't understand, Loung looses interest and crawls out of his arms. (They could turn on the radio at one point and it could add to the information about.

Data analysis:

Loung doesn't want to ask her Pa and they turn on the radio to find the information. This is not attractive for Loung. As Loung doesn't understand what they are talking about.

\section{Data 2}

Loung: I am going to kill them one day. You don't think I can? I can.

Chou: I don't want you to, I don't want you to kill or hurt anyone.

Data analysis:

\section{Conclusion}

Loung Ung and $\mathrm{Pa} / \mathrm{Mr}$. Ung are the main character of "First They Killed My Father. They become the main focus of the audience in the film, and they become the actor so that the audience would be interested in watching the film. Then, there are four issues or topics about the characterization that have been discussed with writer. They are about personality, physical appearance, social status, and social relationship. First about the physical appearance, Loung Ung is little girl, slender build, caramel skin. Loung is passive girl, a vengeful and brave. The second main character is $\mathrm{Pa} / \mathrm{Mr}$. Ung. Male, average body, noon shape eyes and caramel skin. $\mathrm{He}$ is brave, love and care, friendly and liar. This film gives some information about the film's story through the attention of characters and the characterization of the story, not only that the reader of this research can gain more understanding, such as human character, high desire and social relationship.
In this data shown that Loung is vengeful person. Because of her hurt she wants to kill the Comrade. Because Loung always see the brutality of Comrade.

D.2. $\mathrm{Pa} / \mathrm{Mr}$. Ung

$\mathrm{Pa} / \mathrm{Mr}$.Ung is liar. In this case all his lies is only to keep him and his family alive.

Data 1

The Khmer Rouge soldier look at Pa's watch with suspicion.

Khmer Rouge Soldier: This is very nice. Who are you have such a nice watch?

$\mathrm{Pa}$ : This is the gift from my boss

Data analysis:

$\mathrm{Pa} / \mathrm{Mr}$. Ung lies about his watch. On that era, watch is valuable things and only rich or officer wear it. But to keep his and family life he lies to the Khmer Rouge soldier.

\section{References}

Jones, E. (1968). Outline of literature: short story, story: novel, and poem. United States of America: The Macmilliam Company.

Jolie, A. (2017). Script of First They Killed My Father: A daughter of Cambodia Remember

Kemal. (2014). Analisis Tokoh dan Penokohan Dalam Hikayat Muda Balia Karya Teuku Abdulah dan M. Nasir. (Vol 2 Nomor 2). STKIP Bina Bangsa Getsempena

Pradopo, R. D. (2003). Prinsip-Prinsip Kritik Sastra Teori dan Penerapannya. Yogyakarta: Gadjah Mada University Press.

Purnawanti. (2016). Kepribadian Tokoh Utama Dalam Novel for The Love of My Son Karya 


\section{Jomingery}

(2020), 3 (1): 19-25

Margaret Davis. (Vol 4 Nomor 2). Universitas Muhammadiyah Malang.

Ung, L. (2000). Memoar of First They Killed My Father. United States

Of America: Harperrcollin,.

Vidhya \& Arjunan, A. (2015). Characterization-An Intrinsic Aspect of Dramatic Text. (Vol 20 Issue 3, Ver 111, PP 76-78).

Madurai Kamraj University. 